\title{
INFORMATION AND COMMUNICATION TECHNOLOGY ENABLED ENERGY EFFICIENCY
}

\author{
MicietA, B.; BinASOVA, V. \& KubineC, L.
}

Abstract: This paper presents research priorities for information and communication technology enabled energy efficiency in manufacturing processes. The development of energy efficiency improves the competitiveness of manufacturing enterprises and reduces the stress on environmental impacts of production processes. Technologies of advanced industrial engineering, new energy efficient technologies and energy efficiency standards are important for sustainability and competitiveness in production management. Energy and environment related research has contributed strongly to energy efficiency. The aim of the research is to describe visions, key research topics, barriers, impacts, key business scenarios and priorities, which can influence energy costs with low associated investment costs.

Key words: Energy efficiency in manufacturing, cost optimization, information and communication technology, advanced industrial engineering, sustainable production
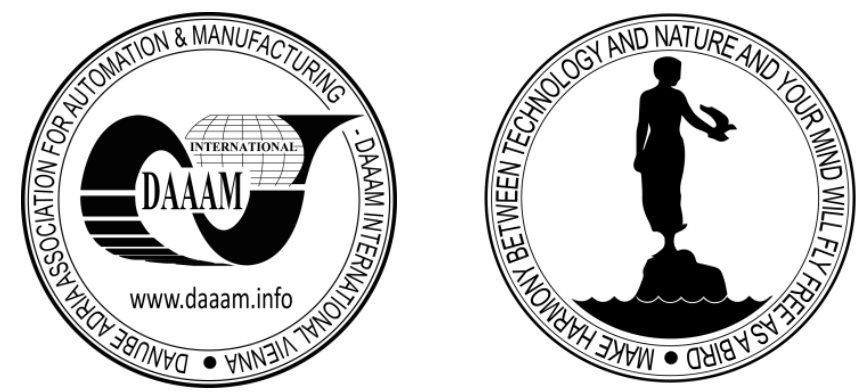

Authors' data: Prof. Ing. PhD. Micieta, $\mathrm{B}[\mathrm{ranislav}]$; Ing. PhD. Binasova, V[ladimira]; Ing. Kubinec, L[ibor], University of Zilina, Faculty of Mechanical Engineering, Univerzitna 8215/1, 01 026, Zilina, Slovakia, branislav.micieta@fstroj.uniza.sk,_ vladimira.binasova@fstroj.uniza.sk, libor.kubinec@fstroj.uniza.sk

This Publication has to be referred as: Micieta, $\mathrm{B}$ [ranislav]; Binasova, V[ladimira] \& Kubinec, L[ibor] (2015). Information and Communication Technology Enabled Energy Efficiency, Chapter 08 in DAAAM International Scientific Book 2015, pp.087096, B. Katalinic (Ed.), Published by DAAAM International, ISBN 978-3-902734-051, ISSN 1726-9687, Vienna, Austria

DOI: 10.2507/daaam.scibook.2015.08 
Micieta, B.; Binasova, V. \& Kubinec, L.: Information and Communication Technol...

\section{Introduction}

The industrial sector produces millions of different products for consumers each year. Investing for example in high-efficiency combined heat and power systems has the potential to save even more.

This paper is structured in the form of five main sections. The first section is introduction to this problem area.

The second section outlines definition of the problem statement of key priorities increasing energy efficiency. The following third section covers the description of key impacts, which can influence energy costs.

Achieving higher end-use efficiency involves a great variety of technical options, because it has little visibility, or politicians, the media, or individuals looking for recognition and acknowledgement, therefore the fourth section discusses in turn the key priorities for information, communication technology enabled energy efficiency in manufacturing, and barriers of greater end-use efficiencies and future research in this area.

The main findings are then summarised in the conclusion.

\section{Definition of the problem statement of key priorities increasing energy efficiency}

This section provides a brief description of four problem statements of key priorities increasing energy efficiency (Fig. 1).

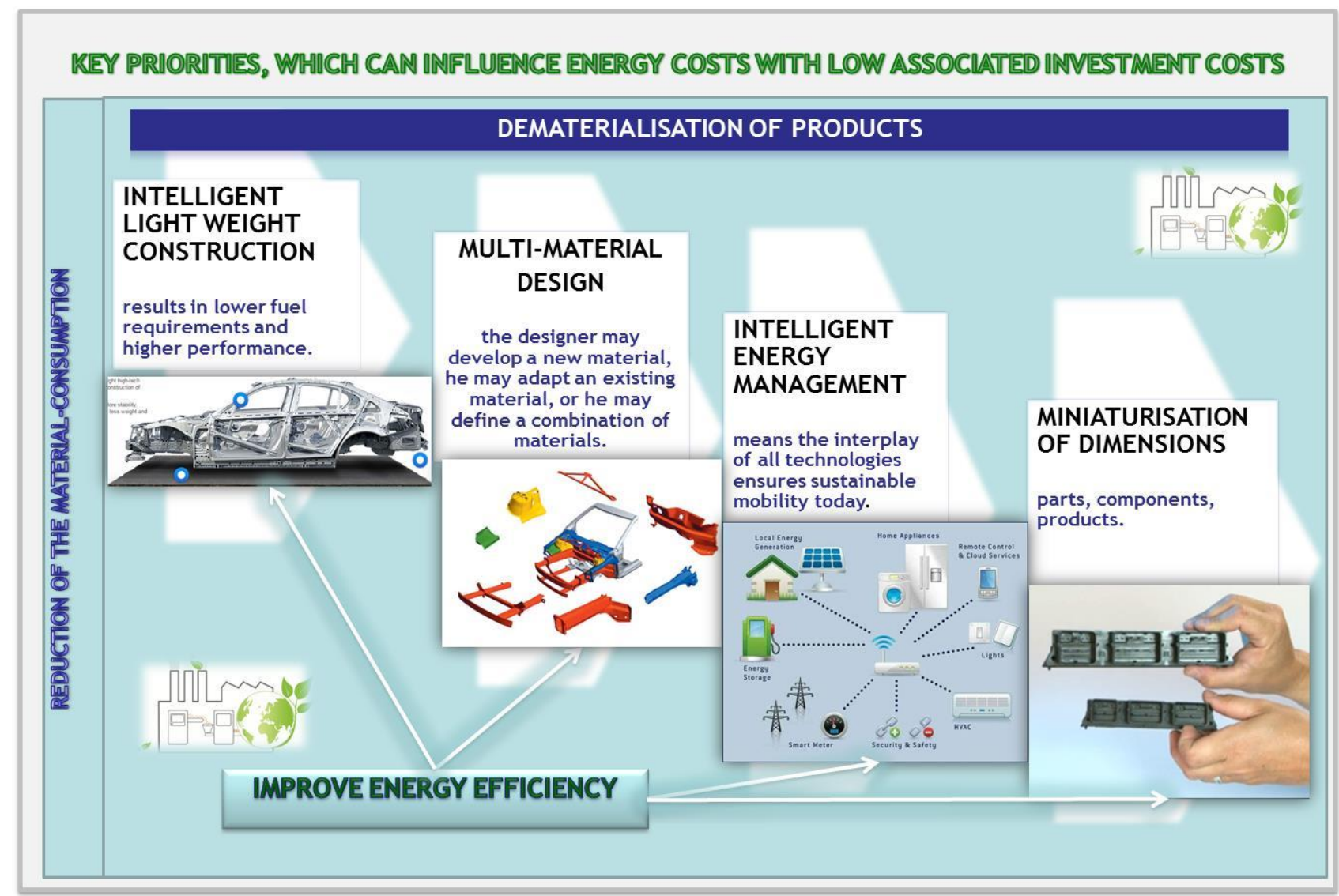

Fig. 1. Key priorities, which can influence energy costs in manufacturing 


\subsection{Intelligent lightweight construction}

For example, there is an intelligent lightweight construction of new cars. Intelligent lightweight construction results in lower fuel requirements and higher performance. Depending on the model, especially lightweight materials are used for the individual parts that make up the body shell, for example, aluminium in the front end and chassis (Kohár \& Hrček, 2014).

This saves an immense amount of weight while simultaneously guaranteeing extremely high stability and excellent passive safety. Light materials like aluminium, the most modern magnesium alloys and carbon-fibre reinforced plastic are used. Carbon-fibre reinforced plastic is a high-tech material that's particularly suited to vehicle manufacture - it's just as stable as steel, but about $50 \%$ lighter.

\subsection{Multi-material design}

Different design strategies are possible depending on the situation. The designer may develop a new material, he may adapt an existing material, or he may define a combination of materials (Bubeník \& Rakyta, M., 2014).

\subsection{Intelligent energy management}

Tomorrow's energy efficient manufacturing will require additional processing power at all levels of its infrastructure. Most wireless sensor nodes presently powered by batteries:

- Battery replacement is costly.

- Self-powered sensors and actuators offer maintenance-free lifecycles and are environment-friendly (Rakyta \& Bubeník, 2014).

Alternative power sources are being developed:

- Solar, vibration, rotation, temperature, organic material.

- May use a capacitor as a buffer when system not in use.

- Low power technology complements these developments and provides low power intelligence (Magvaši \& Gregor, 2013).

- The characteristics of industry are large and high spaces, fixed working positions, long work periods, adverse conditions, various levels of illuminance, high bay lighting, central lighting control, restricted maintenance opportunities. The above characteristics are also clear significant energy consumption for lighting. (Kralikova, et al., 2014).

\subsection{Miniaturisation of dimenzions}

Miniaturization of part is a strong draw in many types of consumer products, but it can be taken too far. For example, mobile phones could be shrunk to the point where keypads and displays would be difficult to use (Dulina \& Bartánusová, 2014). Increasingly, product designers are challenged to provide easy-to-use man-machine interfaces despite higher product complexity and shrinking control-panel real estate. Many electronic devices have already reached a near optimal form factor.

Future miniaturization will focus more and more on increasing a product's sophistication, performance, and market penetration (Krajčovič et al., 2013). 
Micieta, B.; Binasova, V. \& Kubinec, L.: Information and Communication Technol...

\section{Description of key impacts, which can influence energy costs}

Realising cost-effective energy efficiency potentials will be beneficial not only for individual energy consumers, but also for the economy as a whole (Mičietová, et al., 2013). For example, saved energy costs can be used to produce energy-saving domestic goods and services. In following part of the paper are described seven key impacts, which can influence energy costs (Fig. 2).

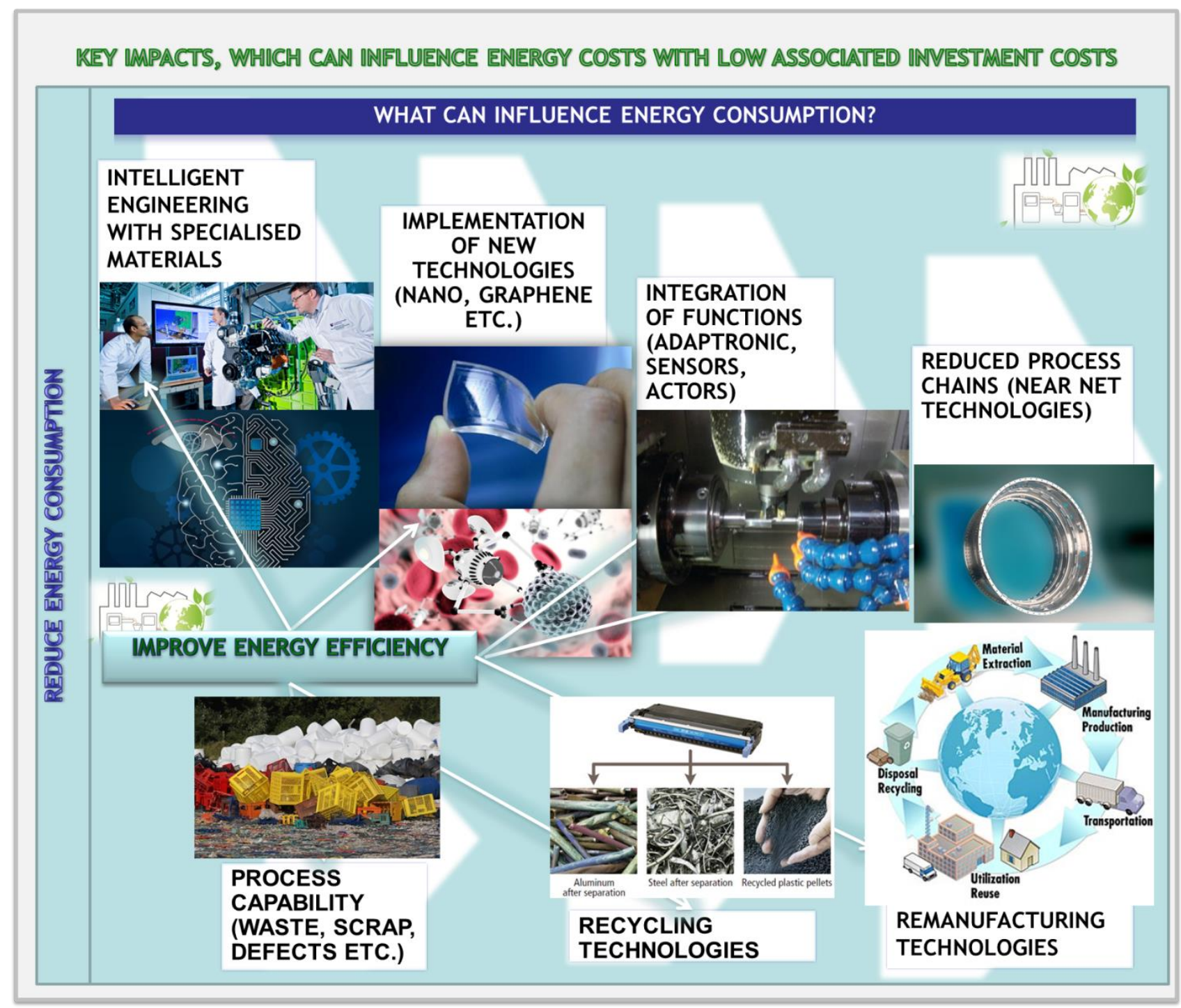

Fig. 2. Key impacts, which can influence energy costs

\subsection{Intelligent engineering with specialised materials}

Intelligent engineering is focused on quality controlling, material properties evaluation as well as institutions is focused on progressive materials production (such as biomaterials, optic wires, micro electric elements, intelligent materials and so.

The present development of new industrial machines which require higher efficiency and cost savings must provide a possibility of higher loadings, higher operating speeds and high reliability with fewer requirements for maintenance (Faturík, et al., 2014). 


\subsection{Implementation of new technologies - nano, graphene}

Graphene sheets could be used for touch screens, just like the ones currently used for credit card terminal signature pads. It's less brittle, less expensive, and performs better than the material currently used for signature pads. But maybe the most exciting new applications on the horizon for graphene take advantage of its inherent antibacterial property. It's super-light and allows a great deal of light to pass through it, so it could be incorporated into anti-bacterial bandages, clothing and other textiles that resist bacterial growth, and even food and live tissue packaging. It seems almost possible that graphene is poised to become the plastic of the future.

Today's scientists and engineers are finding a wide variety of ways to deliberately make materials at the nanoscale to take advantage of their enhanced properties such as higher strength, lighter weight, increased control of light spectrum, and greater chemical reactivity than their larger-scale counterparts.

\subsection{Integration of functions - adaptronic, sensors, actors}

Adaptive structure technology, briefly called adaptronic, is an innovative, new cross sectional technology for the optimization of structure systems (Hnát, 2013).

The adaptive structure technology is based on functional integration by combining conventional structures with active material systems, which extend classical loadbearing and form-defining structure performance by including sensor and actuator functioning. In connection with suitable adaptive controller systems, adaptive structure systems can adapt to their respective operational environment optimally. (Grznár \& Hnát, 2014).

\subsection{Reduced process chains - near net technologies, near net shape production}

Near net shape production is concerned with the manufacture of components; whereby shaping is realized mostly by nonchipping manufacturing techniques and finishing by cutting is reduce to a minimum. Near net shape manufacturing involves such objectives as reducing the number of process stages, minimizing costs, and guaranteeing enhanced product quality.

\subsection{Process capability - waste, scrap, defects}

By employing the statistical process control techniques, in an automated, real-time fashion, many of customers also report they are able to simultaneously:

- Increase product quality.

- Improve production capacity.

- Reduce product waste, scrap, etc.

- Enhance productivity.

The process, which involves waste for the production of energy, is named as waste-to-energy and energy-from-waste. This is a process, which recovers energy from the waste materials, and in which energy is gained through the process of combustion directly or sometimes fuel is produced from waste, which is the source for energy. An innovative approach to planning, evaluation of audits, deadlines and workshops in order to obtain outputs interactively, with room on-line display of the selected group of workplaces. There is possible to control not only the planned date, outputs of the 
analysis in tables and graphs but also to watch video recording or other desired plan activities.

An innovative approach to planning, evaluation of audits, deadlines and workshops in order to obtain outputs interactively, with room on-line display of the selected group of workplaces. There is possible to control not only the planned date, outputs of the analysis in tables and graphs but also to watch video recording or other desired plan activities.

For example, in pneumatic installations leads to energy losses caused by adverse loss of air pressure. Air leak reaches the installation of production enterprises probably $20 \%$ of the compressed air. In following Figure 3 is shown an example of measurement of air leaks in laboratory conditions in Zilina intelligent manufacturing system (ZIMS).

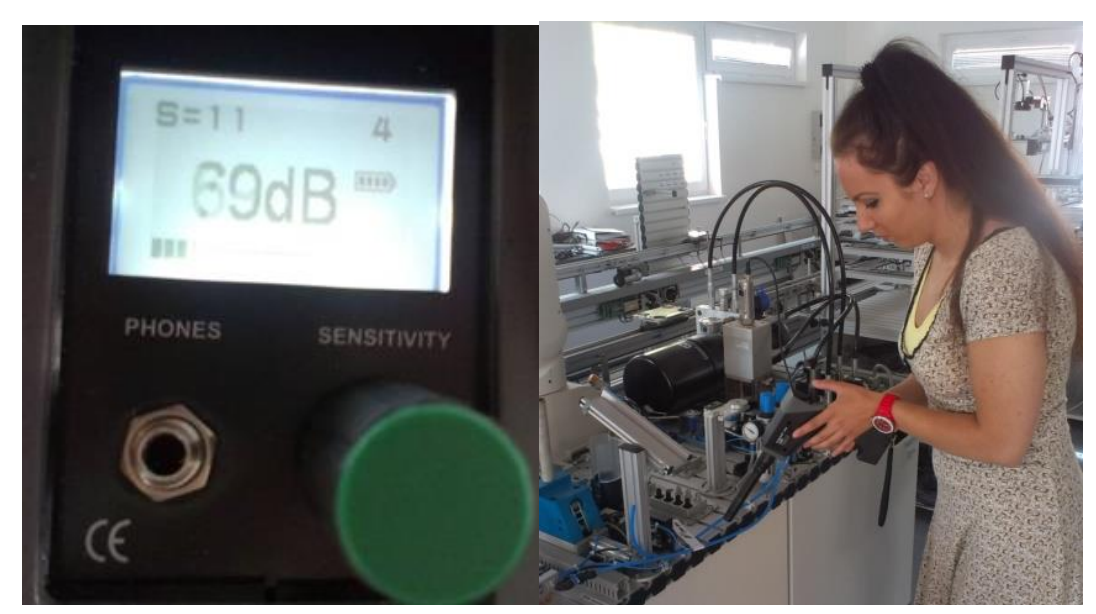

Fig. 3. An example of air leaks in laboratory conditions

\subsection{Recycling technologies}

Over the past several decades, the globalization of the manufacturing ecosystem has driven change, which impacted many companies around the world. Plenty of them benefited from the rapid globalization of industry and expansion of manufacturing. However, these also led to a change in the competitive environment of manufacturing companies (Gastermann, Stopper \& Katalinic, 2012).

Recycling technologies provides innovative solutions to help producers achieve financial gains through turning mixed waste into a valuable resource. The specialized recycling machines (e.g., discs screens separators, shredders, bag openers, glass cleanup systems, over belt magnets, eddy current separators) integrate and improve your recycling system needs. Recycling equipment can also be used for more specific applications such as recycling plastics, cardboard recycling and compactors for waste transfer station.

Reducing energy waste in manufacturing enterprises helps reduce manufacturing costs, and helps keep our industries competitive. But energy waste isn't as easy to identify and address as scrap material that can be swept off the manufacturing enterprise floor and repurposed. Many manufacturers simply don't see wasted energy, because they're not looking for it. Or, as is more often the case, they don't have knowledge or the means to address the problem. 


\subsection{Remanufacturing technologies}

Remanufacturing is generally seen as the most environmentally friendly of end of life treatments for a retired product. If the remanufactured product can be considered a substitute for a new product, then a credit is usually claimed for the avoided resource use and emissions associated with the new product production.

The biggest savings is generally from the avoided new materials production, but the difference between new manufacturing and remanufacturing can also be significant.

At the same time, remanufactured products generally sell for about $50-80 \%$ of the new product. Hence remanufacturing can be seen as a win-win; it saves money (for the consumer) and it saves the environment.

\section{Results - Key priorities for information and communication technology enabled energy efficiency in manufacturing}

Result was identified to the significant barriers, primarily market imperfections that could be overcome by targeted policy instruments as prevent the realization of greater end-use efficiencies. These barriers of greater end-use efficiencies are shown in Figure 4.

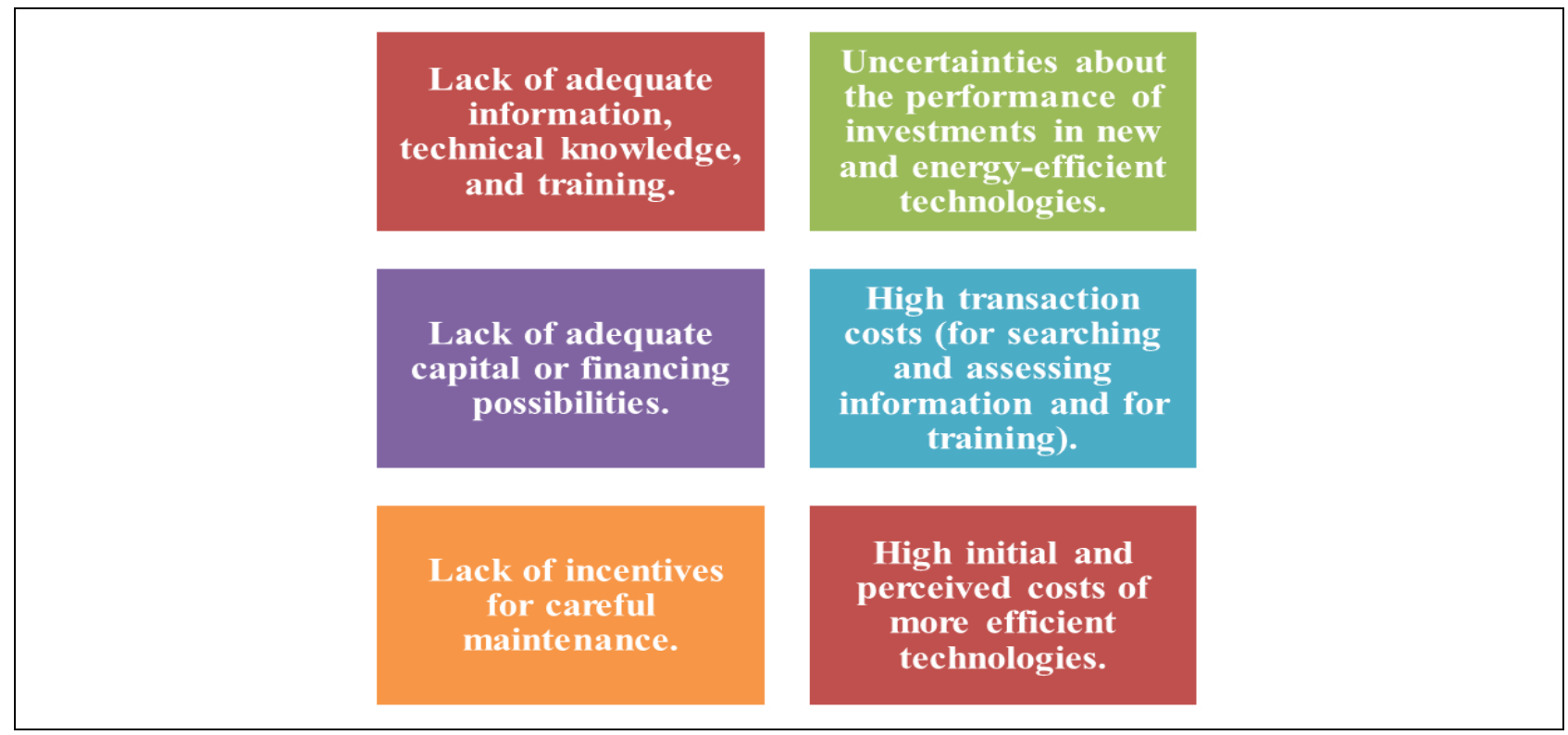

Fig. 4. The barriers of greater end-use efficiencies

To gather a better understanding of the current state of research and gap analysis of research and technology development activities specific to information and communication technology usage for energy efficiency in manufacturing the study was realized.

The main categories served as the basis for structuring the work within this study. These main categories were:

- Tools for energy efficient design \& production management.

- Tools and equipment for intelligent control.

- Energy management and energy standardization. 
Micieta, B.; Binasova, V. \& Kubinec, L.: Information and Communication Technol...

- User awareness \& decision support.

- Support of information and communication technology.

- Integration technologies.

Key research challenges and priorities for information and communication technology enabled energy efficiency in manufacturing for each of the main categories are presented in the Figure 5.

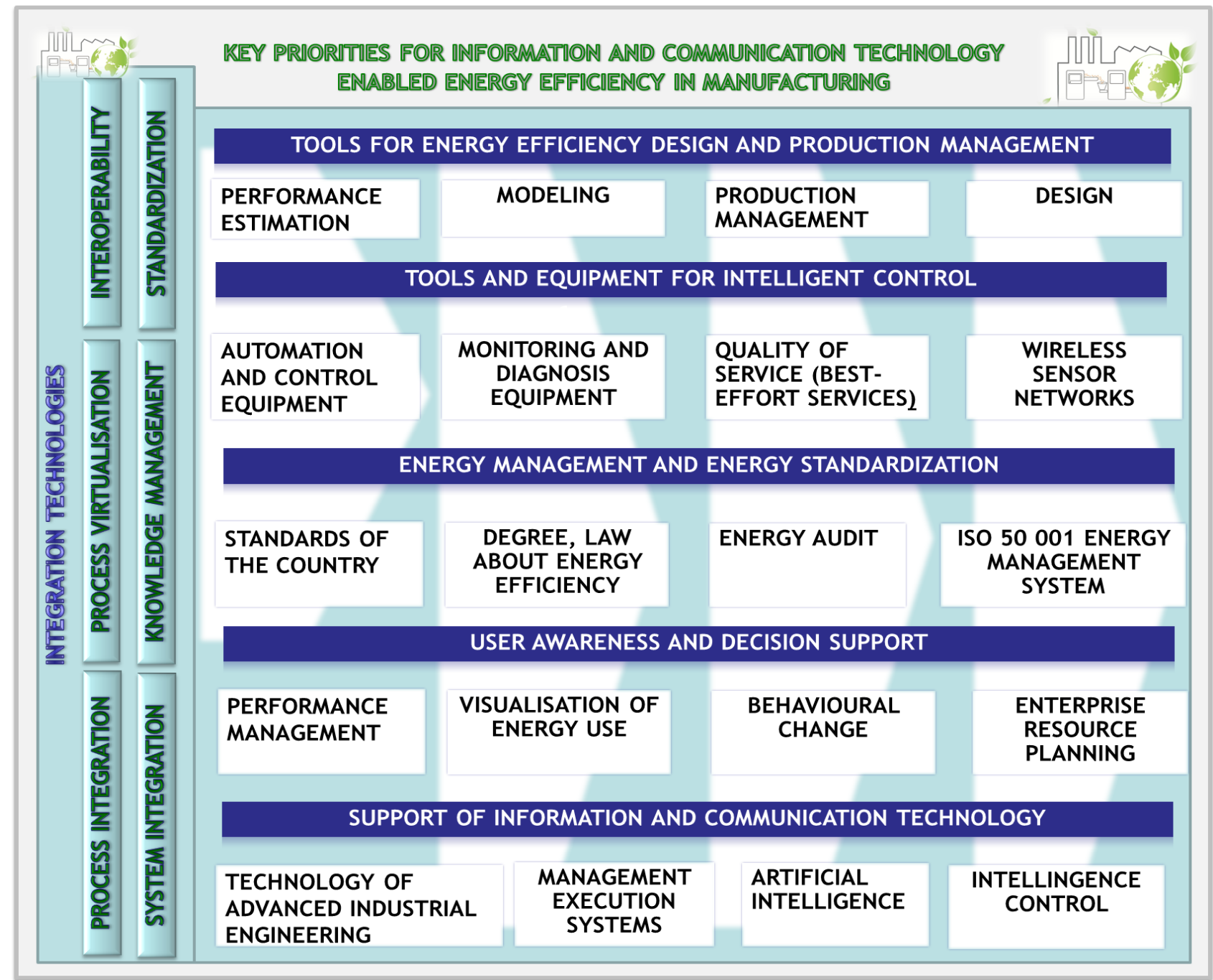

Fig. 5. Key priorities for information and communication technology enabled energy efficiency in manufacturing

Key priorities for information and communication technology enabled energy efficiency in manufacturing and the measurement of their indicators is carried out according to use areas, energy variables, energy performance indicators (EnPi) and energy sources as in the previous case, but with the added feature of being a remote system.

This way, energy management can be carried out in enterprises with distributed centres, facilitating the work of the follow up auditor of energy consumption and planning. In the Figure 6 is shown the advanced approach of energy efficient manufacturing in next generation manufacturing systems. 
During implementation of key priorities is important to collect operational data collection, interactive decision support system, operating procedure, preventive and corrective maintenance.

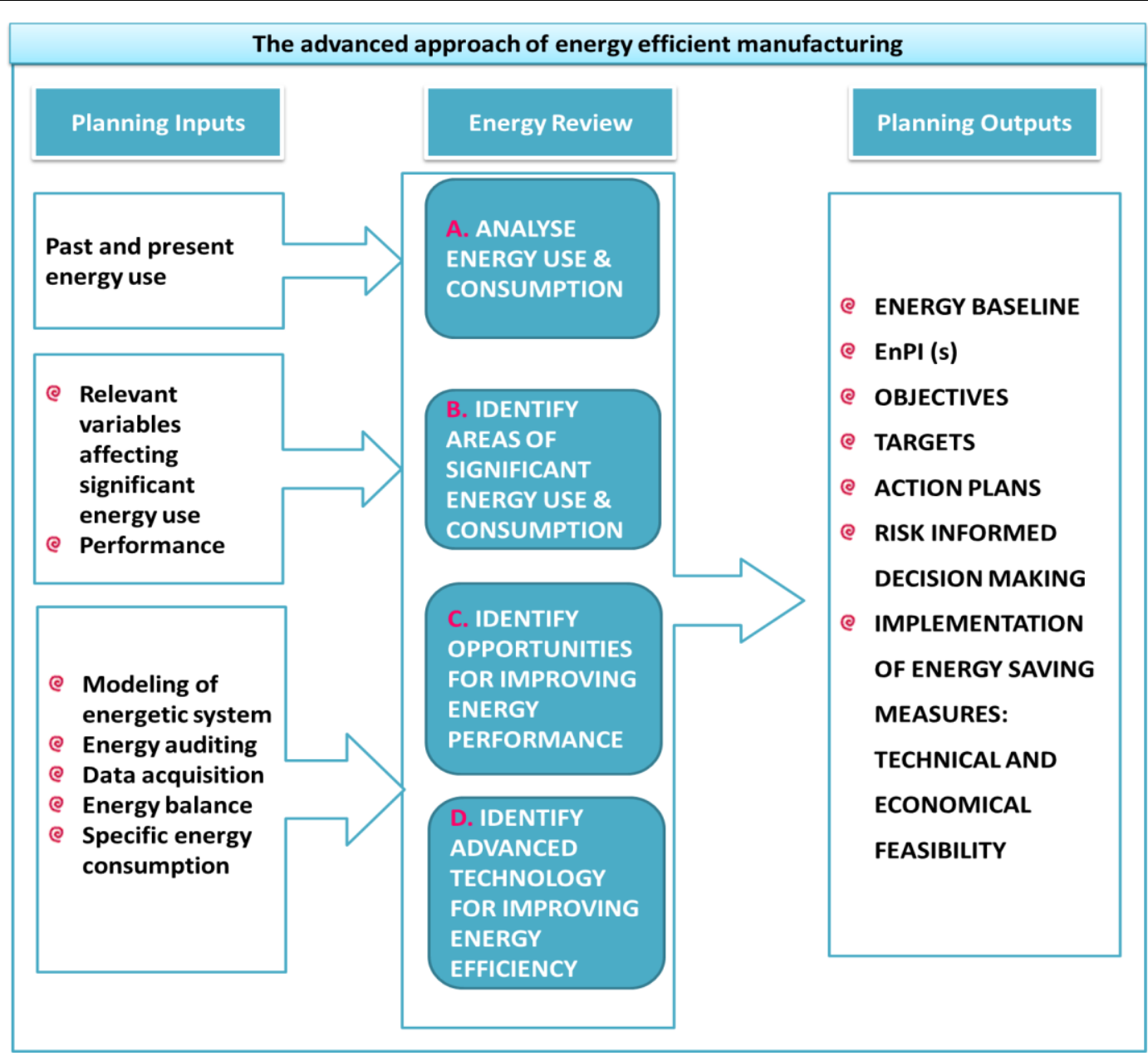

Fig. 6. Basic concept of energy planning (inputs and outputs of energy efficient manufacturing)

\section{Conclusion}

This paper presents study of key priorities for information and communication technology enabled energy efficiency in sustainable manufacturing in sustainable production and description of key impacts and priorities, which can influence energy costs. Therefore, new methods, tools and technologies for increasing energy efficiency in manufacturing are still in the process of development. Further research intends to specify the concept and to develop a demonstrator for using these methods by next case studies. In further research, results should be transferred into industrial practice.

\section{Acknowledgements}

This paper is the part of research supported by project VEGA 1/0559/15. 
Micieta, B.; Binasova, V. \& Kubinec, L.: Information and Communication Technol...

\section{References}

Bubeník, P. \& Rakyta, M. (2014). Data mining technology and its benefits in business practice, In: Manufacturing systems today and tomorrow 2014, Liberec, ISBN 978-807494-150-4

Dulina, L. \& Bartánusová, M. (2014). CAVE design using in digital factory, Proceedings of Procedia Engineering: international symposium on intelligent manufacturing and automation, Katalinic, B. (Ed.), DAAAM 2014, Vol. 100, pp. 291298, ISSN 1877-7058, Vienna

Faturík, L. et al. (2014). Comparison of structural design in high and ultra-high cycle fatigue regions. In: Transactions of FAMENA, Vol. 38, no. 4 (2014), pp. 1-12, ISSN $1333-1124$

Gastermann, B.C.; Stopper, M. \& Katalinic, B. (2012). Adapting CONWIP Characteristics for Conventional Production Planning. In DAAAM International Scientific Book 2012, pp. 553-564, Editor B. Katalinic, Publisher by DAAAM International, ISBN 978-3-901509-86-5, Vienna, Austria

Grznár, P. \& Hnát, J. (2014). Automation of production logistics, In: ProIN. Vol. 15, No. 1, pp. 36-37, ISSN 1339-2271

Hnát, J. (2013). Assembly line balancing problem solved by genetic algorithm, In: AIE: monograph, Bielsko-Biała, pp. 7-8, ISBN 978-83-927531-6-2

Kohár, R. \& Hrček, S. (2014). Dynamic analysis of a rolling bearing cage with respect to the elastic properties of the cage for the axial and radial load cases, In: Communications, Vol. 16, no. 3A (2014), pp. 74-81, ISSN 1335-4205

Krajčovič, M. et al. (2013). Intelligent manufacturing systems in concept of digital factory. In: Communications, Vol. 15, No. 2, pp. 77-87, ISSN 1335-4205

Kralikova, R. et al. (2014) Energy Saving Techniques and Strategies for Illumination in Industry. Proceedings of Procedia Engineering: international symposium on intelligent manufacturing and automation, Katalinic, B. (Ed.), DAAAM 2014, Vol. 100, pp. 291-298, ISSN 1877-7058, Vienna

Magvaši, P. \& Gregor. M. (2013). Advanced industrial engineering and quality of industrial enterprises. In: Quality of Products from the quality of responsibility and innovation, pp. 38-42, ISBN 978-80-553-1466-2, Kosice

Mičieta, B. \& Stollmann, V. (2011). Assembly Line Balancing. In DAAAM International Scientific Book 2011, pp. 257-264, Editor B. Katalinic, Publisher by DAAAM International, ISBN 978-3-901509-84-1, ISSN 1726-9687, Vienna, Austria Mičietová, A.; Neslušan M.; Čilliková M. \& Ochodek V. (2013). Analysis of high and low frequency Barkhausen noise for detection grinding burn Proceedings of international congress on engineering and technology, pp. 27-38, ISBN 978-80-87670-08-8, 2013, RISE Association, Prague

Rakyta, M. \& Bubeník, P. (2014). Practical requirements for maintenance systems and experiences from the implementation of TPM. In: Manufacturing systems today and tomorrow: 8th international conference, 2014. ISBN 978-80-7494-150-4, Liberec Staszewska, J. (2013). The company Industrial towards the challenges of the twentyfirst century. Krakow and Warsaw: Unique, 2013. ISBN 978-83-62314-80-5 (in Polish) 